\author{
Agnieszka Wojcieszak \\ Uniwersytet im. Adama Mickiewicza w Poznaniu \\ wojcieszak-agnieszka@wp.pl \\ Katarzyna Arciszewska \\ Uniwersytet im. Adama Mickiewicza w Poznaniu \\ k.arciszewska@op.pl
}

\title{
Sytuacja osób ubezwłasnowolnionych w procesie wyrażania zgody na zabieg medyczny. Wybrane zagadnienia
}

\author{
Situation of the incapacitated in granting consent to medical treatment. \\ Selected Issues
}

\begin{abstract}
A basic right of every patient is the right to grant consent to medical treatment. A doctor cannot act without the knowledge and will of a patient. Contrary behaviour is treated as illegal. Use of the right to self-determination becomes complicated when the patient is incapacitated and this article presents the process of granting consent to medical treatment when this situation arises. Particular attention has been paid to describe the situation of a partially incapacitated patient. The reflections presented lead to the conclusion that under Polish legislation, an incapacitated patient is not completely deprived of the possibility of expressing their will. It is also important that the right to self-determination of an incapacitated patient should be respected by the physician throughout the entire term of treatment. The whole discussion aims at presenting the scope of the autonomy of incapacitated patients in the context of substitute consent and double consent.
\end{abstract}

Keywords: autonomy, patient's consent, incapacitation

Słowa kluczowe: autonomia, zgoda pacjenta, ubezwłasnowolnienie

\section{Wprowadzenie}

Podstawowym prawem każdego pacjenta jest możliwość współdecydowania o całym procesie leczenia. Przejawia się ona w możliwości wyrażenia przez pacjenta zgody na przeprowadzenie zabiegu medycznego. Lekarz nie może zatem podejmo- 
wać jakichkolwiek czynności, jeśli pacjent nie wyraził swojej woli ${ }^{1}$. Uzależnienie przeprowadzenia zabiegu medycznego od uzyskania stosownej zgody jest gwarancją poszanowania autonomii pacjenta.

Szczególną uwagę należy zwrócić na niejasno uregulowaną sytuację prawną osób ubezwłasnowolnionych. Problemy związane z możliwością udzielenia relewantnie prawnej zgody przez pacjenta ubezwłasnowolnionego pojawiają się zarówno w ustawie z dnia 5 grudnia 1996 r. o zawodach lekarza i lekarza dentysty ${ }^{2}$, jak również w ustawie z dnia 6 listopada 2008 r. o prawach pacjenta i Rzeczniku Praw Pacjenta ${ }^{3}$.

Zarówno w ustawie o zawodach lekarza i lekarza dentysty (dalej „u.z.l”), jak i ustawie o prawach pacjenta i Rzeczniku Praw Pacjenta (dalej: „u.p.p.”) ustawodawca posługuje się zwrotem „osoba ubezwłasnowolniona”. Takie rozwiązanie powoduje spore trudności interpretacyjne. W doktrynie na tle wykładni przepisów art. 32-34 u.z.l. zaproponowano, aby pojęcie „ubezwłasnowolniony”, występujące bez sprecyzowania, o które ubezwłasnowolnienie chodzi, było interpretowane jako obejmujące jedynie osoby ubezwłasnowolnione całkowicie ${ }^{4}$. Wydaje się, że takie stwierdzenie nie jest słuszne i dostrzec w nim można pewne sprzeczności.

W niniejszym artykule przedstawiona zostanie analiza wybranych zagadnień związanych z sytuacją osób ubezwłasnowolnionych w procesie wyrażania zgody na zabieg medyczny ${ }^{5}$. W szczególności zostanie zaprezentowana problematyka zgody przedstawiciela ustawowego osoby ubezwłasnowolnionej całkowicie, zgody lub zezwolenia sądu opiekuńczego oraz zgody przedstawiciela ustawowego i osoby ubezwłasnowolnionej.

\section{Zgoda przedstawiciela ustawowego osoby ubezwłasnowolnionej całkowicie}

Zarówno w przypadku zabiegów prostych, jak i o podwyższonym ryzyku wobec ubezwłasnowolnionego całkowicie, zgoda zastępcza przedstawiciela ustawowego ma charakter obligatoryjny (art. 32 ust. 4 i art. 34 ust. 3 u.z.l.). Przedstawicielem

\footnotetext{
Z zastrzeżeniem wyjątków przewidzianych w ustawodawstwie z zakresu prawa medycznego.

Tekst jedn. Dz.U. z 2017 r., poz. 125, ze zm.

Tekst jedn. Dz.U. z 2016 r., poz. 186, ze zm.

A. Zoll, Granice legalności zabiegu medycznego, „Prawo i Medycyna” 1999, nr 1, s. 37-38.

Należy wskazać, że odrębnego potraktowania wymagają zagadnienia związane z charakterem zgody oraz dokonywaniem przez osoby ubezwłasnowolnione czynności prawnych. Szerzej: M. Pazdan, Komentarz do art. 13 i 16, (w:) System Prawa Prywatnego, Tom 1, Prawo cywilne - część ogólna, M. Safjan (red.), Warszawa 2012, s. 1080-1105; K. Mularski, Czynności podobne do czynności prawnych, Warszawa 2011, s. 212 i nast.; P. Księżak, Komentarz do art. 13 i art. 16, (w:) Kodeks cywilny. Komentarz. Przepisy wprowadzające. Część ogólna. Własność i inne prawa rzeczowe, K. Osajda (red.), Warszawa 2013, s. 356 i nast.; J. Strzebinczyk, Komentarz do art. 13 i art. 16, (w:) Kodeks cywilny. Komentarz, E. Gniewek, P. Machnikowski (red.), Warszawa 2016, s. 42 i nast.; L. Kociucki, Zdolność do czynności prawnych osób dorosłych i jej ograniczenia, Warszawa 2011, s. 107249; A. Olejniczak, Z. Radwański, Prawo cywilne - część ogólna, Warszawa 2013, s. 260-268; B. Janiszewska, Zgoda na udzielenie świadczenia zdrowotnego. Ujęcie wewnątrzsystemowe, Warszawa 2013, s.82 i nast.; M. Tomaszewska, Charakter prawny decyzji o ubezwłasnowolnienie w sądowym stosowaniu prawa, Toruń 2008, s. 67-96.
} 
ustawowym osoby ubezwłasnowolnionej całkowicie jest opiekun. Zgodnie z art. 175 k.r.o. ${ }^{6}$ do opieki nad ubezwłasnowolnionym całkowicie stosuje się odpowiednio przepisy o małoletnim. Istotne z punktu widzenia tej regulacji jest to, że aktualne będą tu wszystkie uwagi o zakresie kompetencji opiekuna i nadzorze sądu opiekuńczego, jakie występują przy zgodzie przedstawiciela ustawowego pacjenta małoletniego do 16. roku życia.

Wypada nadmienić, że dla osoby ubezwłasnowolnionej całkowicie, która ukończyła 13 lat i pozostaje pod wpływem władzy rodzicielskiej, nie jest ustanawiana opieka ${ }^{7}$. W takim przypadku zgodę zastępczą mogą wyrazić rodzice, jako przedstawiciele ustawowi ubezwłasnowolnionego całkowicie małoletniego ${ }^{8}$.

Warto w tym miejscu zwrócić szczególną uwagę na niejasno uregulowaną sytuację prawną osób ubezwłasnowolnionych częściowo. $Z$ analizy art. 32 ust. 1-4 u.z.l. nie wynikają jakiekolwiek ograniczenia odnoszące się do ich autonomii woli. W konsekwencji, należałoby przyjąć, że osoba ubezwłasnowolniona częściowo, jeżeli jest w pełni świadoma, może sama decydować o przeprowadzeniu badania. Taka możliwość dotyczy tylko prostych zabiegów medycznych (jak wynika z art. 34 ust. 1 i 3 u.z.l. lekarz może wykonać zabieg operacyjny albo zastosować metodę leczenia lub diagnostyki stwarzającą podwyższone ryzyko dla pacjenta ubezwłasnowolnionego tylko po uprzednim uzyskaniu zgody zastępczej) $)^{9}$. Zdaniem M. Filara, pacjent częściowo ubezwłasnowolniony jest uprawniony do wyrażenia zgody, o ile stan jego zdrowia pozwala mu na świadome podjęcie decyzji ${ }^{10}$. Także T. Dukiet-Nagórska twierdzi, że możliwe jest skuteczne wyrażenie woli przez ubezwłasnowolnionego częściowo, jeśli działa $z$ rozeznaniem ${ }^{11}$. Wydaje się, że stanowisko prezentowane przez doktrynę jest słuszne. Biorąc pod uwagę racjonalność aksjologiczną prawodawcy, należy uznać, że jeżeli osoby ubezwłasnowolnione całkowicie posiadają kompetencje do wyrażenia swojej woli (art. 32 ust. 4 zd. 2 u.z.l.), to również w odniesieniu do osoby, której psychiczne możliwości są większe, należy przyznać takie uprawnienie. Wątpliwości mogą pojawić się w sytuacji, gdy sąd wyznaczy kuratora dla osoby ubezwłasnowolnionej częściowo w związku z nieracjonalnym podejmowaniem przez tę osobę działań w zakresie ochrony zdrowia.

$6 \quad$ Tekst jedn. Dz.U. z 2017 r., poz. 682, ze zm.

$7 \quad$ Zob. S. Kalus, (w:) K. Piasecki (red.), Kodeks rodzinny i opiekuńczy. Komentarz, Warszawa 2011, s. 830.

$8 \quad$ Zob. M. Świderska, Zgoda pacjenta na zabieg medyczny, Toruń 2007, s. 52.

$9 \quad$ Ibidem, 41-42.

10 M. Filar, Postępowanie lecznicze (świadczenie zdrowotne) w stosunku do pacjenta niezdolnego do wyrażenia zgody, „Prawo i Medycyna” 2003, nr 13, s. 43; podobnie: M. Safjan, Prawo i medycyna. Ochrona praw jednostk a dylematy współczesnej medycyny, Warszawa 1998, s. 52; A. Suchocka, Zakres działań lekarskich w fazie sztucznego podtrzymywania życia w prawie polskim i międzynarodowym, „Przegląd Prawa Europejskiego” 2001, nr 1, s. 51; J. Kulesza, Brak zgody pacjenta na zabieg leczniczy a lekarski obowiązek udzielania pomocy, „Prawo i Medycyna" 2005, nr 19, s. 74 i nast.; A. Kołodziej, Stopień autonomii woli pacjenta na tle ustawy o zawodzie lekarza i ustawy o ochronie zdrowia psychicznego, „Prawo i Medycyna” 2002, nr 11, s. 79; M. Świderska, Zgoda pacjenta..., op. cit., s. 41.

11 T. Dukiet-Nagórska, Świadoma zgoda pacjenta w ustawodawstwie polskim, „Prawo i Medycyna” 2000, nr 6/7, s. 91. 
Problemy związane z możliwością udzielenia relewantnie prawnej zgody przez pacjenta ubezwłasnowolnionego częściowo pojawiają się wraz z odpowiednim zastosowaniem art. 32 ust. 6 u.z.l. Dla uniknięcia nieścisłości związanych z sytuacją prawną osoby ubezwłasnowolnionej częściowo należałoby doprecyzować art. 32 ust. 6 u.z.l. Jak słusznie postuluje M. Świderska, wystarczy w treści przepisu zaznaczyć, że odnosi się on tylko do osób ubezwłasnowolnionych całkowicie, a nie częściowo, poprzez dodanie słowa "całkowicie” ${ }^{12}$. Wydaje się, że autorka ma rację. Zaproponowane rozwiązanie umożliwiłoby zachowanie spójności między przepisami ustawy oraz doprowadziło do jasnego i konsekwentnego uregulowania przez ustawodawcę sytuacji prawnej osób ubezwłasnowolnionych częściowo.

$\mathrm{Z}$ kolei $\mathrm{w}$ drugim $\mathrm{z}$ analizowanych przypadków bez wątpienia wymagana będzie zgoda sądu opiekuńczego. Wynika to wprost $\mathrm{z}$ art. 32 ust. 6 u.z.l. Zgodnie z tym przepisem, w przypadku sprzeciwiania się czynnościom medycznym przez pacjenta, poza zgodą jego przedstawiciela ustawowego lub opiekuna faktycznego albo w przypadku niewyrażenia przez nich zgody, wymagane jest zezwolenie sądu opiekuńczego ${ }^{13}$.

Sytuacja osób ubezwłasnowolnionych częściowo komplikuje się również w związku z treścią art. 17 i 18 u.p.p. Wielu problemów nastręcza relacja przytoczonych przepisów do ustawy o zawodach lekarza i lekarza dentysty. Zdaniem R. Kubiaka należałoby przyjąć, że ustawa o prawach pacjenta stanowi lex generalis wobec ustawy o zawodach lekarza i lekarza dentysty ${ }^{14}$. Należy zgodzić się z postulatem przedstawionym przez autora. Ustawa o prawach pacjenta odnosi się bowiem do wszystkich świadczeń medycznych, zaś ustawa o zawodach lekarza i lekarza dentysty reguluje tylko zabiegi wykonywane przez lekarzy. A zatem w myśl zasady lex specialis derogat legi generali pierwszeństwo należy przyznać przepisom szczególnym, a więc ustawie o zawodach lekarza i lekarza dentysty ${ }^{15}$.

Przyjęcie powyższej zasady zmierza do rozwiązania problemów związanych $\mathrm{z}$ jednoczesnym stosowaniem obu ustaw, które nie są względem siebie koherentne. Zgodnie $\mathrm{z}$ art. 17 ust. 2 u.p.p., zgoda przedstawiciela ustawowego jest wymagana w przypadku osoby całkowicie ubezwłasnowolnionej. Przepis ten jest zgodny z art. 32 ust. 4 u.z.l. Natomiast art. 18 u.p.p., który dotyczy zabiegów operacyjnych, w ust. 1 stanowi, że do wyrażenia zgody na taki zabieg odpowiednie zastosowanie ma art. 17 ust. 2 u.p.p. $Z$ kolei w ust. 3 wprost nakazuje stosować art. 17 ust. 2-4 u.p.p. Konstrukcja i wzajemne relacje przytoczonych przepisów są niespójne w sytuacji osób ubezwłasnowolnionych częściowo. W przypadku zabiegów prostych zgoda zastępcza jest wymagana tylko wobec osób ubezwłasnowolnionych całkowicie, a przepisy te stosuje się także do zabiegów operacyjnych, co oznacza, że osoby ubezwłasnowolnione

\footnotetext{
12 Ibidem, s. 41-42.

13 Zob. P. Dzienis, Zgoda pacjenta jako warunek legalności leczenia, „Przegląd Sądowy” 2001, nr 11/12, s. 78; J. Kulesza, Brak zgody pacjenta na zabieg leczniczy a lekarski obowiązek udzielania pomocy, op. cit., s. 77, M. Safjan, Prawo i medycyna, op. cit., s. 52-53.

14 R. Kubiak, Prawo medyczne, Warszawa 2010, s. 349.

15 Ibidem, s. 349.
} 
częściowo mogą samodzielnie podejmować decyzje zarówno w przypadku zabiegów prostych, jak i operacyjnych. Jak podkreśla R. Kubiak, takie założenie pozostaje w sprzeczności z art. 34 ust. 3 u.z.l., który nakazuje wykorzystywanie zgody zastępczej bez względu na rodzaj ubezwłasnowolnienia ${ }^{16}$.

Z powyższego wynika, że jednoczesne stosowanie obu ustaw może prowadzić do poważnych problemów praktycznych. Dlatego też należy uznać prymat ustawy o zawodach lekarza i lekarza dentysty jako ustawy lex specialis wobec ustawy o prawach pacjenta.

\section{Zgoda udzielona przez opiekuna faktycznego}

Rozważając problematykę zgody substytucyjnej, warto wspomnieć o kompetencjach tzw. opiekuna faktycznego. W myśl przepisów ustawy opiekunem faktycznym jest osoba sprawująca, bez obowiązku ustawowego, stałą opiekę nad pacjentem, który ze względu na wiek, stan zdrowia albo stan psychiczny opieki takiej wymaga (art. 3 ust. 1 pkt 1 u.p.p.). Użyty w przytoczonej definicji element stałości pieczy eliminuje wszelkie przypadki czasowego opiekowania się pacjentem. Zasadniczo zatem krąg podmiotów, które mogą być uznane za opiekunów faktycznych, jest stosunkowo wąski. Opiekunem faktycznym może zostać m.in. kurator osoby ubezwłasnowolnionej częściowo, któremu sąd nie przyznał prawa do reprezentacji.

O uprawnieniach opiekuna faktycznego stanowi art. 32 ust. 3 u.z.l. W myśl tego przepisu, w odniesieniu do dokonywania badań osoby małoletniej lub niezdolnej do wyrażenia zgody wystarczająca jest zgoda opiekuna faktycznego. W literaturze twierdzi się, że opiekun faktyczny może wyrazić zgodę jedynie na badanie, a nie na dalsze świadczenia zdrowotne. ${ }^{17} \mathrm{~W}$ konsekwencji, opiekun może wyrazić zgodę wyłącznie na rutynowe i niestwarzające zagrożenia dla życia i zdrowia czynności medyczne ${ }^{18}$. Co ciekawe, w innych przepisach ustawodawca przewidział możliwość wyrażenia przez opiekuna faktycznego zgody na czynności medyczne (art. 32 ust. 6 u.z.l.), a także udzielenie świadczeń zdrowotnych (art. 32 ust. 8 i art. 33 ust.1 u.z.l.) ${ }^{19}$.

16 R. Kubiak, Prawo medyczne, op. cit., s. 348-349.

17 Zob. M. Nesterowicz, Nowe ustawodawstwo medyczne, „Państwo i Prawo” 1997, z. 9, s. 6; R. Kubiak, Prawo medyczne, op. cit., s. 350; R. Kędziora, Problematyka zgody pacjenta w świetle polskiego ustawodawstwa medycznego, „Państwo i Prawo” 2003, z. 7/8, s. 48; B Janiszewska, Zgoda na udzielenie..., op. cit., s. 551.

18 M. Safjan, Prawo i medycyna, op. cit., s. 45. Słusznie wskazuje B. Janiszewska, że opiekun faktyczny wypowiada się w przedmiocie zgody na badanie, jeżeli pacjent małoletni, ubezwłasnowolniony lub niezdolny do świadomego wyrażenia zgody nie ma przedstawiciela ustawowego lub też wprawdzie ma takiego przedstawiciela, lecz nie istnieje możliwość porozumienia się z nim w czasie, w którym zachodzi potrzeba przeprowadzenia badania, B. Janiszewska, Zgoda na udzielenie..., op. cit., s. 559.

19 Wypada dodać, że zgodnie z art. 10b ust. 1 ustawy z dnia 19 sierpnia 1994 r. o ochronie zdrowia psychicznego (tekst jedn. Dz.U. z 2017 r., poz. 882 ze zm.) opiekun faktyczny ma prawną możliwość wyrażenia zgody na wgląd w dokumentację medyczną przez Rzecznika Praw Pacjenta Szpitala Psychiatrycznego. Co ciekawe, przepis ten choć sprzeczny z ustawą z dnia 6 listopada 2008 r. o prawach pacjenta i Rzeczniku Praw Pacjenta, nadal jest obowiązujący. 
Wydaje się, że konieczne byłoby sprecyzowanie zakresu uprawnień opiekuna faktycznego. Problemów nastręcza również fakt, że uprawnienia opiekuna faktycznego są znacznie ograniczone. Pojawia się zatem pytanie co zrobić w sytuacji, gdy rodzice dziecka, które osiągnęło niedawno pełnoletniość, tracą definitywnie prawo do decydowania o losie tego dziecka, nawet wtedy gdy chodzi o jego życie i zdrowie. Zdaniem M. Świderskiej, względy słuszności oraz istnienie więzi emocjonalnej jakie $\mathrm{z}$ reguły łączy się z relacjami rodzinnymi czy też partnerskimi uzasadniają prima facie nadanie szerszych kompetencji tzw. opiekunowi faktycznemu ${ }^{20}$. Jednocześnie postulat o rozszerzeniu kompetencji opiekuna faktycznego nie może powodować obniżenia poziomu ochrony autonomii woli pacjenta, ustalonego $\mathrm{w}$ ustawie ${ }^{21}$. $\mathrm{Z}$ tej racji, rozszerzenie zakresu uprawnień opiekuna faktycznego musi być poparte racjonalnymi argumentami, które wynikają z okoliczności, w jakich pacjent się znajduje.

\section{Zgoda lub zezwolenie Sądu Opiekuńczego}

Rozstrzygnięcie sądowe występuje w sytuacji, gdy brak jest podmiotu posiadającego kompetencje do wyrażenia zgody, ewentualnie jego wola jest sprzeczna $z$ interesem pacjenta i może zostać przełamana zezwoleniem sądowym ${ }^{22}$. Wymienione przypadki korzystania ze zgody sądowej zostały wcześniej omówione, toteż ograniczamy się tylko do ich przypomnienia i podsumowania.

Po pierwsze, zgodnie $\mathrm{z}$ art. 32 ust. 2 u.z.l. zgoda sądu opiekuńczego jest konieczna w sytuacji, gdy osoba małoletnia lub niezdolna do świadomego wyrażenia zgody nie ma przedstawiciela ustawowego lub gdy porozumienie z nim jest niemożliwe. Innymi słowy, niemożność skontaktowania się z przedstawicielem ustawowym lub jego utrata powoduje, że proces decyzyjny przejmuje na siebie sąd. Działa on nie tylko w zastępstwie pacjenta, ale również przedstawiciela ustawowego.

Ponadto, ustawodawca nie uregulował sytuacji prawnej osób ubezwłasnowolnionych całkowicie, gdy te nie posiadają przedstawiciela ustawowego albo porozumienie $\mathrm{z}$ nim jest niemożliwe, a konieczne jest podjęcie leczenia. Jak wynika $\mathrm{z}$ art. 32 ust. 4 u.z.l., osoba ubezwłasnowolniona całkowicie nie posiada zdolności do samodzielnego wyrażenia zgody. W piśmiennictwie wskazuje się, że jest to luka w prawie i należy odpowiednio stosować analogię legis ${ }^{23}$. Tym samym, konieczne będzie uzyskanie rozstrzygnięcia przez sąd.

Ze zgodą substytucyjną spotykamy się również w sytuacji osób posiadających pełną zdolność do czynności prawnych, ale niezdolnych do świadomego wyrażenia

20 M. Świderska, Zgoda pacjenta..., op. cit., s. 59.

21 Ibidem, s. 59.

22 R. Kubiak, Prawo medyczne, op. cit., s. 355; B. Pawelczyk, Zasady wyrażania zgody oraz prawo do prywatności pacjentki ciężarnej, referat wygłoszony na konferencji naukowej: Podmiotowość pacjentki ciężarnej i rodzącej, Chełmża, 10-11.11.2007 r., niepubl. 
zgody. Podmioty takie nie posiadają przedstawiciela ustawowego. Dlatego też, sąd opiekuńczy powinien wydać w tym zakresie odpowiednie orzeczenie.

$\mathrm{Z}$ ingerencją sądu opiekuńczego mamy do czynienia także w razie kolizji woli między pacjentem a jego przedstawicielem ustawowym (opiekunem faktycznym), albo w razie przełamania sprzeciwu przedstawicieli ustawowych. Jak słusznie zauważa M. Świderska, sąd opiekuńczy działa tu jako rozjemca, który musi starannie wyważyć racje stron i nadać im właściwe proporcje ${ }^{24}$. W literaturze wielokrotnie postuluje się, ażeby znowelizować art. 36 ust. 2 u.z.l. Według przedstawicieli doktryny, przepis ten jest w swej treści zbyt liberalny i otwiera drogę do pomijania zarówno woli pacjenta, jak i jego przedstawiciela ustawowego ${ }^{25}$.

Nie podzielamy powyższego poglądu. Oczywiście, trudno nie przyznać racji, że przepis ten budzi spore zastrzeżenia, niemniej jednak lekarz również w przypadkach nagłych może decydować o przeprowadzeniu zabiegu bez pytania kogokolwiek o zgodę. Dlatego też zgadzamy się z M. Świderską, która słusznie twierdzi, że trudno odmówić podobnej kompetencji wymiarowi sprawiedliwości przy wskazywaniu na racje, jakimi powinien kierować się przy orzekaniu.

Zgodnie z art. 32 ust.10 u.z.l. właściwym do wydania zezwolenia jest sąd opiekuńczy, w okręgu którego czynność medyczna ma być wykonana. Postępowanie o uzyskanie zgody zastępczej przeprowadzane jest w trybie art. 579 k.p.c. W wypadkach nagłych sąd może rozpoznać sprawę w trybie uproszczonym - bez przeprowadzania rozprawy. Z przypadkiem nagłym mamy do czynienia w sytuacji, gdy każda chwila zwłoki grozi ciężkimi konsekwencjami dla zdrowia i życia, lekarz może działać wtedy nawet bez zgody sądu opiekuńczego (art. 32 ust. 9. u.z.l. oraz art. 34 ust. 7 u.z.l.). ${ }^{26}$ Wydane orzeczenia stają się wykonalne $\mathrm{z}$ chwilą wydania albo ogłoszenia.

\section{Zgoda przedstawiciela ustawowego i osoby ubezwłasnowolnionej}

Za osobę ubezwłasnowolnioną całkowicie zgodę wyraża jej przedstawiciel ustawowy. Natomiast, jeżeli osoba taka jest w stanie z rozeznaniem wypowiedzieć opi-

\footnotetext{
$24 \quad$ Ibidem, s. 55.

25 Zob. A. Kołodziej, Stopień autonomii woli...,op. cit., s. 81; A. Liszewska, Zgoda pacjenta na zabieg leczniczy, „Państwo i Prawo” 1997, z. 1, s. 89; M. Safjan, Prawo i medycyna, op. cit., s. 53.

26 Szerzej: M. Śliwka, Prawo pacjenta do świadczenia opieki zdrowotnej w stanie nagłym, „Prawo i Medycyna” 2008, nr 2, s. 44 i nast.; M. Filar, S. Krześ, E. Marszałkowska-Krześ, P. Zaborowski, Odpowiedzialność lekarzy i zakładów opieki zdrowotnej, Warszawa 2004, s. 193; M. Filar, Postępowanie lecznicze..., op. cit., s. 44; J. Bujny, Prawa pacjenta - między autonomią a paternalizmem, Warszawa 2007, s. 248 i nast.; J. Kulesza, Brak zgody pacjenta..., op. cit., s. 70-71; A. Zoll, Stan wyższej konieczności jako okoliczność wyłączająca przestępczość w praktyce lekarskiej, „Prawo i Medycyna” 2005, nr 19, s. 13; M. Świderska, Zgoda pacjenta..., op. cit., s. 172176; T. Dukiet-Nagórska, Stan wyższej konieczności..., op. cit., s. 22; A. Zoll, Granice legalności zabiegu medycznego, op. cit., s. 29; R. Kędziora, Problematyka zgody pacjenta..., op. cit., s. 41 i nast.; K. Daszkiewicz, Uchylenie odpowiedzialności lekarza za wykonanie zabiegu leczniczego bez zgody pacjenta, „Palestra” 2002, nr 11/12, s. 37 i nast.; K. Sakowski, Komentarz do art. 34 ustawy o zawodach lekarza i lekarza dentysty, System Informacji Prawnej Lex.
} 
nię w sprawie badania, konieczne jest ponadto uzyskanie jej zgody ${ }^{27}$. Ustawa nie definiuje pojęcia zdolności do wyrażenia zgody. Zdaniem R. Kędziory należy przyjąć, że jest to zdolność do logicznego wyrażenia opinii odnośnie czynności. Autorka zauważa, że ograniczenie tego przepisu tylko do badania budzi uzasadnione wątpliwości ${ }^{28}$. Według T. Dukiet-Nagórskiej, takie rozwiązanie powoduje, że w myśl argumentum a minori ad maius, zgoda powinna być odbierana od osoby ubezwłasnowolnionej również przy świadczeniach zdrowotnych innych niż badanie ${ }^{29}$. Zgadzamy się z autorką. Uważamy, że człowiek, który potrafi z rozeznaniem wyrazić swoją wolę w sprawie przeprowadzenia badania, posiada taką samą zdolność do wypowiadania się w sprawie innych świadczeń zdrowotnych. Jak podkreśla M. Świderska, taka aprobata ze strony osoby pozbawionej zdolności do czynności prawnych umożliwia zachowanie poczucia godności poprzez świadomość wpływu na zachowanie swojej integralności cielesnej ${ }^{30}$.

W przypadku dokonywania zabiegów operacyjnych lub stwarzających podwyższone ryzyko, ustawodawca pominął możliwość wyrażenia zgody przez osoby ubezwłasnowolnione całkowicie, ale dysponujące dostatecznym rozeznaniem dla wyrażenia swojej woli (art. 34 ust. 4 u.z.l.). Naszym zdaniem nie należy pozbawiać ich prawa do samostanowienia. Za uwzględnieniem woli osób ubezwłasnowolnionych przemawia chociażby norma wyrażona w art. 6 ust. 3 Konwencji bioetycznej. Zgodnie z treścią analizowanego przepisu wobec osoby dorosłej, która nie ma zdolności do wyrażenia zgody na interwencję medyczną z powodu zaburzeń czynności psychicznych, choroby albo innych podobnych powodów, interwencja medyczna może być przeprowadzona za zgodą jej przedstawiciela ustawowego, odpowiedniej władzy albo innej osoby lub instytucji ustanowionych w tym celu na mocy przepisów prawa, a osoba poddana interwencji medycznej powinna, jeśli jest to możliwe, uczestniczyć w podejmowaniu decyzji ${ }^{31}$.

W związku z powyższym, uważamy, że ustawodawca polski powinien zapewnić poszerzanie ochrony autonomii pacjenta, który jest w stanie wyrazić jednak świadomie swoją wolę i umożliwić mu prawo do decydowania o swoim ciele, choćby jako zgodę kumulatywną.

Wprowadzenie konstrukcji zgody kumulatywnej może powodować kolizję woli pacjenta i jego przedstawiciela ustawowego lub też opiekuna faktycznego, gdy chodzi o zgodę na badanie. Jak już było to wspomniane przy okazji zgody przedstawiciela i lekarza dentysty, System Informacji Prawnej Lex; J. Haberko, B. Pawelczyk, Poszanowanie autonomii pacjentki w zakresie udzielania przez nią zgody na zabiegi medyczne, „Ginekologia i Położnictwo - Medical Project” 2009, nr 1, s. 42-43.

28 R. Kędziora, Problematyka zgody pacjenta, op. cit., s. 49.

29 T. Dukiet-Nagórska, Świadoma zgoda pacjenta w ustawodawstwie polskim, op. cit., s. 91.

30 M. Świderska, Zgoda pacjenta..., op. cit., s. 64.

31 Konwencja o ochronie praw człowieka i godności istoty ludzkiej w dziedzinie zastosowania biologii i medycyny, Oviedo, 4 kwietnia $1997 \mathrm{r}$. 
Sytuacja osób ubezwłasnowolnionych w procesie wyrażania zgody...

ustawowego i osoby małoletniej od 16 lat, w przypadku rozbieżności stanowisk tych osób, wymagana będzie zgoda sądu opiekuńczego (art. 32 ust. 6 i art. 34 ust. 5 u.z.l.).

\section{Podsumowanie}

Ustawodawca polski nie traktuje pacjenta ubezwłasnowolnionego jako osoby a priori niezdolnej do świadomego wyrażenia zgody, ale przeciwnie, zasadą czyni potrzebę uzyskania zgody takiego pacjenta, chociażby w przypadku badania przeprowadzanego przez lekarza. Niemniej jednak problematyczna zdaje się być kwestia zakresu autonomii woli pacjenta. Wydaje się, że zakres autonomii pacjenta powinien zależeć od zdolności jego postrzegania i wyrażania woli. Wobec tego, trudno jednoznacznie pozbawiać możliwości wyrażenia swojej woli osoby nieubezwłasnowolnione, u których widoczne są nawroty zaburzeń psychicznych. W świetle obecnie obowiązujących przepisów posiadają one pełną zdolność do czynności prawnych, co powoduje, że mają one możliwość wyrażenia zgody na zabieg medyczny.

Przedstawione rozważania na temat osób ubezwłasnowolnionych skłaniają ku stwierdzeniu, że na gruncie polskiego ustawodawstwa pacjent ubezwłasnowolniony nie jest całkowicie pozbawiony możliwości wyrażania swojej woli, jednak są to w ocenie autorek zbyt daleko idące ograniczenia i godzą w prawo do samostanowienia. Co istotne, prawo do samostanowienia pacjenta ubezwłasnowolnionego powinno być respektowane przez lekarza w całym procesie jego leczenia.

\section{BIBLIOGRAFIA}

Bujny J., Prawa pacjenta - między autonomią a paternalizmem, Warszawa 2007.

Daszkiewicz K., Uchylenie odpowiedzialności lekarza za wykonanie zabiegu leczniczego bez zgody pacjenta, „Palestra” 2002, nr 11/12.

Dukiet-Nagórska T., Stan wyższej konieczności w działalności lekarskiej, „Prawo i Medycyna” 2005, nr 2.

Dukiet-Nagórska T., Świadoma zgoda pacjenta w ustawodawstwie polskim, „Prawo i Medycyna” 2000, nr 6/7.

Dzienis P., Zgoda pacjenta jako warunek legalności leczenia, „Przegląd Sądowy” 2001, nr 11/12.

Filar M., Krześ S., Marszałkowska-Krześ E., Zaborowski P., Odpowiedzialność lekarzy i zakładów opieki zdrowotnej, Warszawa 2004.

Filar M., Postępowanie lecznicze (świadczenie zdrowotne) w stosunku do pacjenta niezdolnego do wyrażenia zgody, „Prawo i Medycyna” 2003, nr 13.

Haberko J., Pawelczyk B., Poszanowanie autonomii pacjentki w zakresie udzielania przez nią zgody na zabiegi medyczne, „Ginekologia i Położnictwo - Medical Project” 2009, nr 1.

Janiszewska B., Zgoda na udzielenie świadczenia zdrowotnego. Ujęcie wewnątrzsystemowe, Warszawa 2013. 
Kalus S., (w:) K. Piasecki (red.), Kodeks rodzinny i opiekuńczy. Komentarz, Warszawa 2011.

Kędziora R., Problematyka zgody pacjenta w świetle polskiego ustawodawstwa medycznego, „Państwo i Prawo" 2003, z. 7/8.

Kociucki L., Zdolność do czynności prawnych osób dorosłych i jej ograniczenia, Warszawa 2011.

Kołodziej A., Stopień autonomii pacjenta na tle ustawy o zawodzie lekarza i ustawy o ochronie zdrowia psychicznego, „Prawo i Medycyna” 2002, nr 11.

Księżak P., Komentarz do art. 13 i art. 16, (w:) Kodeks cywilny. Komentarz. Przepisy wprowadzające. Część ogólna. Własność i inne prawa rzeczowe, K. Osajda (red.), Warszawa 2013.

Kubiak R., Prawo medyczne, Warszawa 2010.

Kulesza J., Brak zgody pacjenta na zabieg leczniczy a lekarski obowiązek udzielania pomocy, „Prawo i Medycyna” 2005, nr 19.

Liszewska A., Zgoda pacjenta na zabieg leczniczy, „Państwo i Prawo” 1997, z. 1.

Mularski K., Czynności podobne do czynności prawnych, Warszawa 2011.

Nesterowicz M., Nowe ustawodawstwo medyczne, „Państwo i Prawo” 1997, z. 9.

Olejniczak A., Radwański Z., Prawo cywilne - część ogólna, Warszawa 2013.

Pawelczyk B., Zasady wyrażania zgody oraz prawo do prywatności pacjentki ciężarnej, referat wygłoszony na konferencji naukowej: Podmiotowość pacjentki ciężarnej i rodzącej, Chełmża, 10-11.11.2007 r., niepubl.

Pazdan M., Komentarz do art. 13 i 16, (w:) System Prawa Prywatnego, Tom 1, Prawo cywilne - część ogólna, M. Safjan (red.), Warszawa 2012.

Safjan M., Prawo i medycyna. Ochrona praw jednostki a dylematy współczesnej medycyny, Warszawa 1998.

Sakowski K., Komentarz do art. 32 i 34 ustawy o zawodach lekarza i lekarza dentysty, System Informacji Prawnej Lex.

Strzebinczyk J., Komentarz do art. 13 i art. 16, (w:) Kodeks cywilny. Komentarz, E. Gniewek, P. Machnikowski (red.), Warszawa 2016.

Suchocka A., Zakres działań lekarskich w fazie sztucznego podtrzymywania życia w prawie polskim i międzynarodowym, „Przegląd Prawa Europejskiego” 2001, nr 1.

Śliwka M., Prawo pacjenta do świadczenia opieki zdrowotnej w stanie nagłym, „Prawo i Medycyna” 2008, nr 2.

Świderska M., Zgoda pacjenta na zabieg medyczny, Toruń 2007.

Tomaszewska M., Charakter prawny decyzji o ubezwłasnowolnienie w sądowym stosowaniu prawa, Toruń 2008.

Zoll A., Granice legalności zabiegu medycznego, „Prawo i Medycyna” 1999, nr 1.

Zoll A., Stan wyższej konieczności jako okoliczność wyłączająca przestępczość w praktyce lekarskiej, „Prawo i Medycyna” 2005, nr 19. 